\title{
O GROTESCO HUMORÍSTICO DE LOURENÇO MUTARELLI: A GARÇONETE E A NOIVA EM O CHEIRO DO RALO
}

\author{
PÂMELLA POSSATTI NEGRELI (UFES - CAPES) ${ }^{1}$ \\ PAULO ROBERTO SODRÉ (UFES) ${ }^{2}$
}

\begin{abstract}
RESUMO: Este artigo tem como objetivo analisar a relação grotescamente humorística do protagonista do romance $\mathrm{O}$ cheiro do ralo com as figuras femininas mais importantes do livro, sua (ex) noiva e a garçonete de uma lanchonete por quem se torna obcecado. Dessa forma, a partir de estudos e fichamentos do humor literário narrativo de um ponto de vista sobretudo linguístico e historiográfico, procuramos detectar, por meio dos recursos humorísticos mais utilizados no romance, a estreita ligação do humor mutarelliano com o grotesco.
\end{abstract}

PALAVRAS-CHAVE: Narrativa brasileira contemporânea, O cheiro do ralo, Humor, Figuras femininas na literatura, Grotesco.

ABSTRACT: This article aims to analyze the grotesquely humorous relationship of the protagonist of the novel "O Cheiro do Ralo" with the most important female figures of the book, his (ex) fiancé and the waitress of a diner by whom he becomes obsessed. Thus, from the studies and records of narrative literary humour from a linguistic and historiographical point of view, we look for detect, through the humorous resources most used in the novel, the close connection between Mutarellian humour and the grotesque.

KEYWORDS: Contemporary Brazilian Narrative, O cheiro do ralo, Humor, Female figures in literature, Grotesque.

\section{INTRODUÇÃO}

Um dos pontos comuns na reflexão sobre o texto humorístico, tanto nos estudos literários como nos historiográficos e linguísticos, é que o riso é o efeito que se espera do receptor. Fazer rir, levar ao riso, provocar o riso, eis a motivação de quem produz esse tipo de texto. A causa para isso, entretanto, pode ser variada. Segundo Luiz Carlos Travaglia (2015, p. 51), a suspensão da credibilidade de um texto pode gerar o riso quando não existir um compromisso com a seriedade. Para Vladímir Propp (1992, p. 24), "Diferentes aspectos de comicidade levam a diferentes tipos de riso". Sendo assim, é complicado definir certeiramente o que é cômico ou não, uma vez que, em geral, essa definição vai depender do contexto humorístico para poder provocar, ou não, o riso. Para Jan Bremmer e Herman Roodenburg (2000, p. 15), é um erro determinar o riso e o humor como "[...] transculturais e anistóricos", pois o riso, assim como o humor, é um fenômeno marcado pela cultura de um determinado tempo e local.

Apesar dessa dificuldade em definir o humor, Roberto Sarmento Lima o concebe em duas partes:

[...] uma, que diz respeito ao humor corrosivo [...] cujo tema pode não conter nada de engraçado, enquanto outra parte evoca explicitudes do tema [...] capaz de despertar, agora sim, a hilaridade.

\footnotetext{
${ }^{1}$ Mestranda no Programa de Pós-Graduação em Letras da Universidade Federal do Espírito Santo (UFES), email: pamellapnegreli@gmail.com

2 Professor associado da Universidade Federal do Espírito Santo (UFES), e-mail: paulorobertosodre.letras@gmail.com
} 


\section{$=$ TRAMA $=$}

No primeiro caso, $[\ldots]$ trata-se de um riso entranhado no discurso, $[\ldots]$ pelas quais ora se ri do herói, ora se ri do próprio ato narrativo, revelando-se a inadequação entre o tema tratado e a linguagem que o tece (LIMA, 2011, p. 87).

Como esclarecido por Lima, existe um tipo de riso que não precisa ser necessária e explicitamente engraçado. É o que acontece, por exemplo, na ironia, no grotesco e, às vezes, no humor negro. Nesses tipos de humor, não conseguimos perceber um sorriso alegre e "lúdico", mas, sim, um sorriso corrosivo, maldoso, triste.

Neste artigo analisaremos O cheiro do ralo de Lourenço Mutarelli (2011) à luz das relações entre humor e grotesco, este que é um dos desdobramentos do humor. O objetivo é observar como Mutarelli narra o que ele considera a vida "vazia" de um homem urbano que atua num comércio de objetos usados e antigos, embora ela seja cheia de "coisas" que o protagonista examina, escolhe, adquire e passa a ter, numa recolha estranha de objetos cheios de histórias alheias e que ele tem o prazer de extrair ou desprezar perversamente. Mais especificamente, atentaremos para as figuras femininas, a garçonete e a ex-noiva, e o tratamento dado à composição humorística grotesca de cada uma.

Considerando que o humor oscila entre o lúdico e o satírico, o ridículo e o feio, o bem e mal-humorado, sua relação com o grotesco não é forçada e nem estranha. Como se sabe, o termo grotesco é definido em língua portuguesa, sinteticamente, como uma "categoria estética", relacionada às artes visuais e à literária:

1 ART. PLÁST diz-se de ou cada um dos ornamentos que representam objetos, plantas, animais e seres humanos ou fantásticos, reunidos em cercaduras, medalhões e frisos que envolvem os painéis centrais de composições decorativas realizadas em estuques e esp. em afrescos; brutesco, grutesco 2 p. ext. ART. PLÁST diz-se de, ou estilo artístico ou obra desenvolvida a partir de tais ornamentos <a pintura g. de Arcimboldo $><0 \mathrm{~g}$. dos flamengos e alemães $>3 \mathrm{p}$. ext. ART. PLÁST CINE FOT LIT TEAT diz-se de ou categoria estética cuja temática ou cujas imagens privilegiam o disforme, o ridículo, o extravagante etc. 4 p. ext. que ou o que se presta ao riso ou à repulsa por seu aspecto inverossímil, bizarro, estapafúrdio ou caricato <situação g.> [...] (HOUAISS; VILLAR, 2009, p. 992).

Para Antônio Houaiss e Mauro de Salles Villar (2009), a imagem grotesca se vincula ao disforme que, dependendo do ponto de vista, pode causar o riso ou a repulsa.

No Dicionário de termos literários, de Massaud Moisés (2013), a origem da palavra grotesco vem de grotta (gruta), e servia para denominar a decoração estranha que foi descoberta no século XV nas paredes de grutas nas Termas de Tito, em Roma. Atualmente, o termo grotesco se refere ao "[...] bizarro, extravagante, caprichoso, mau gosto, irregular e, mesmo, ridículo" (MOISÉS, 2013, p. 217-219).

O ridículo de que tratam Houaiss e Villar e Moisés é um dos pontos de conexão com o grotesco, em geral associado com o hiperbólico ou exagerado. Como explica Vladímir Propp (1992, p. 91), "O grau mais elevado e extremo do exagero é o grotesco. [...] No grotesco o exagero atinge tais dimensões que aquilo que é aumentado já se transforma em monstruoso".

Seguindo para uma definição mais especializada, um clássico na discussão do termo é o prefácio Do grotesco e do sublime (2010), presente na obra Cromwell (1843), de Victor Hugo, no qual é feita uma reflexão sobre dualidades na literatura da época, o que seria a nova tendência do drama contemporâneo para o autor: feio $\mathrm{x}$ bonito, grotesco $\mathrm{x}$ sublime, etc. Ou seja, um novo jeito de se fazer literatura emergia, recheado com esse dualismo, e o grotesco teria um papel imenso a exercer, porque na modernidade (do autor) "[...] o drama, é o grotesco com o sublime, a alma sob o corpo, é uma tragédia sob uma comédia. [...] o trágico no cômico, o alegre no terrível" (HUGO, 2010, p. 95). Também, o grotesco é "[...] uma das supremas 


\title{
$=$ TRAMA $=$
}

belezas do drama" (HUGO, 2010, p. 50), chegando a ser, muitas vezes, uma necessidade no drama moderno. Ainda sobre o grotesco, Hugo afirma que o mesmo, "[...] de um lado, cria o disforme e o horrível; do outro, o cômico e o bufo" (HUGO, 2010, p. 30-31). Lados estes que parecem estar por todo $\mathrm{O}$ cheiro do ralo, como poderemos evidenciar nos diversos exemplos que serão expostos mais à frente.

Wolfgang Kayser, no também clássico O grotesco, explica que

\begin{abstract}
Na palavra grottesco, como designação de uma determinada arte ornamental, estimulada pela Antiguidade, havia para a Renascença não apenas algo de lúdico e alegre, leve e fantasioso, mas, concomitantemente, algo angustiante e sinistro em face de um mundo em que as ordenações de nossa realidade estavam suspensas, ou seja: a clara separação entre os domínios dos utensílios, das plantas, dos animais e dos homens, bem como da estática, da simetria, da ordem natural das grandezas (2009, p. 20).
\end{abstract}

A convivência entre riso e angústia proporcionados pelo grotesco entra em pauta. Além disso, Kayser o define como uma estrutura: "o grotesco é o mundo alheado (tornado estranho)" (2009, p. 159), um mundo visto pela visão da loucura. Ou seja, a estrutura "normativa" da vida, do mundo, não é mais tão segura ou confiável. Quando a própria vida se torna estranha e fora de ordem, quando não se percebe mais o controle nas coisas cotidianas, a percepção do mundo, inevitavelmente, se tornará, no mínimo, deturpada ou, até mesmo, louca.

Mikhail Bakhtin (1987), em Cultura popular na Idade Média e no Renascimento: o contexto de François Rabelais, diferencia o grotesco medieval do grotesco romântico ou contemporâneo (para sua época). Para o autor, o grotesco medieval (e renascentista) se pauta $(m)$ naquilo que sempre pode se regenerar, por isso traz renovação e alegria, transformando o medo em carnaval. Assim sendo, esse grotesco está "[...] associado à cultura cômica popular, representa o terrível através de espantalhos cômicos, isto é, na forma do terrível vencido pelo riso. O terrivel adquire sempre um tom de bobagem alegre" (BAKHTIN, 1987, p. 34). Ao contrário do medieval e renascentista, o grotesco romântico ou contemporâneo é "[...] terrivel e alheio ao homem. Tudo o que é costumeiro, banal, habitual, reconhecido por todos, torna-se subitamente insensato, duvidoso, estranho e hostil [...]" (BAKHTIN, 1987, p. 34).

Dos estudos mais recentes sobre o grotesco, temos Introdução ao grotesco nas artes da cena, artigo de Odilon José Roble e Raíssa Guimarães de Souza Araújo. Para os autores, "[...] a comédia de cunho grotesco se reporta aos aspectos mais primitivos do mundo ordinário [...] referindo-se diretamente aos desejos, instintos e necessidades" (ROBLE; ARAÚJO, 2016, p. 151). A respeito do grotesco atual, eles explicam:

\begin{abstract}
Ainda que se apresente, frequentemente, em uma roupagem cômica, o grotesco possui forte aspecto existencialista, uma vez que se ocupa de representar deformações que são fruto da relação entre aspectos naturais da condição humana e um sistema de normas impostas. Corpo e mente, vício e moral, sagrado e profano, indivíduo e sociedade, tragédia e comédia, vida e morte são aspectos opostos, em princípio, que são intimamente relacionados por meio do grotesco de modo a provocar um aguçamento das sensibilidades (ROBLE; ARAÚJO, 2016, p. 152).
\end{abstract}

Os autores trazem para nossa discussão um ponto importante: o grotesco cômico e seu aspecto existencialista. Os binômios levantados por eles, "corpo e mente" e "indivíduo e sociedade", talvez contornem mais claramente o drama do protagonista do romance, ou a sua comédia, na medida em que sua ironia, sem dúvida autodefensiva, tangencia sempre o 


\section{$=$ TRAMA $=$}

desespero de quem está à beira de um ataque de riso (diante de sua fragilidade e, em especial, das pessoas que o cercam em sua casa e em sua loja) ou de loucura (diante do nonsense da vida).

Ao tratar do grotesco nas mídias do cinema, da literatura e da televisão, Muniz Sodré e Raquel Paiva, em O império do grotesco, explicam que na literatura "[...] o grotesco irrompe em situações marcadas pelo conflito entre as leis da realidade empírica e as figurações excêntricas encenadas pela imaginação artística" (2002, p. 74), o que nos leva à constatação de que o grotesco está intimamente ligado ao que foge do nosso controle, do real e da ordem das coisas - certamente, quase um mundo "fantástico" criado pelo autor.

Esses variados aspectos do grotesco, evidenciados pelos que vêm discutindo seu conceito e sua dimensão na cultura, é que entram em pauta na leitura de O cheiro do ralo, publicado em 2011. Adaptado para o cinema, esse romance de Mutarelli se destaca pela imbricação da deformação e do horrível, do cômico e do bufo, como percebeu certeiramente Victor Hugo (2010) já no século XIX.

Em O cheiro do ralo, um narrador em primeira pessoa conta sua história: numa loja cujo ralo do banheiro está entupido e causando um mau cheiro que o está deixando louco, ele comercializa objetos antigos, vê-se obcecado pela bunda de uma garçonete de bar de quinta categoria, além de ficar fixado, também, por alguns dos objetos que compra (como o olho de vidro) e, ainda, resolve romper o noivado às vésperas de se casar. Nessa narrativa, portanto, vários traços do grotesco e do humor são postos em atuação.

Diante do odor que emerge do banheiro de sua loja, o protagonista vai perdendo sua sanidade à medida em que o cheiro ruim aumenta, acarretando-lhe a ocorrência de coisas estranhas que não encontram explicação, deixando-o amargurado. Como observa Kayser (2009, p. 159), "No caso do grotesco não se trata de medo da morte, porém de angústia de viver. Faz parte da estrutura do grotesco que as categorias de nossa orientação no mundo falhem". O protagonista, refém de seu ceticismo, envereda-se por uma "angústia de viver" que só encontra relativo consolo ao se deparar com objetos inesperados, como a "bunda" e o olho de vidro (MUTARELLI, 2011, p. 36), nos quais incide especialmente o grotesco, pois o afeto ou o interesse são estimulados não pelo rosto atraente de uma mulher, mas por sua bunda, nem pelos olhos expressivos de alguém, mas por um olho de vidro. Tal contrassenso é explicado pelo que Kayser considera, no grotesco, "[...] o contraste pronunciado entre forma e matéria (assunto), a mistura centrífuga do heterogêneo, a força explosiva do paradoxal, que são ridículos e horripilantes ao mesmo tempo" (2009, p. 159). Nesta perspectiva, Mutarelli elabora seu protagonista como aquele que, desamarrado das convenções (o noivado rompido), se desespera diante de um mundo sem sentido, caótico, ilustrado pela série de personagens igualmente desesperançados que o procuram para vender seus "objetos cheios de história" (MUTARELLI, 2011, p. 12). A comercialização desses objetos caros às lembranças de cada um exemplifica na narrativa a derrocada dos valores afetivos, todos reduzidos à venda, ao comércio.

\section{"SUA BUNDA, IMENSA E DISFORME, SORRIU PARA MIM": A GARÇONETE}

Embora o cheiro do ralo seja impactante na composição do grotesco - e por essa razão figura como título da narrativa -, a primeira e mais forte aparição deste no romance ocorre logo em seguida ao encontro que o protagonista tem com o encantatório e obsessivo na forma da "bunda" de uma garçonete de um bar, onde o personagem principal faz sua péssima refeição todos os dias: "Quando me dei conta, contemplava uma bunda enorme. Farta. Quase disforme" (MUTARELLI, 2011, p. 10-11). 


\section{$=$ TRAMA $=$}

Um dos aspectos principais na composição do grotesco, seja nas artes visuais, seja na literatura, é o exagero na descrição dos elementos: "O exagero, o hiperbolismo, a profusão, o excesso são, segundo opinião geral, os sinais característicos do estilo grotesco" (BAKHTIN, 1987, p. 265). Além disso, o grotesco "[...] é constituído pelo disforme, pelo horroroso [...]" (KAYSER, 2009, p. 59), como apontou antes Victor Hugo (2010, p. 30-31) em seu prefácio oitocentista.

A bunda "disforme", exagerada, gigantesca, fora do comum, segundo o ponto de vista do vendedor, é o que este consegue observar obcecadamente no corpo da garçonete, abstraindo sua condição de homem doente e a refeição ruim que a dona da bunda lhe serve. Nesse sentido, a descrição do protagonista sobre a mulher a partir de seu baixo corporal traseiro corresponde ao que, no texto grotesco, se expõe de modo hipertrofiado, uma vez que "[...] no grotesco, o exagero é de um fantástico levado ao extremo, tocando a monstruosidade" (KAYSER, 2009, p. 267). É o que se percebe na visão obsedante do narrador-personagem, agora enfeitiçado por aquela parte que apaga toda a individualidade da mulher, que ele tenta conquistar para, ao fim, estar perto do rabo fantasticamente desejável.

Vale notar, como ressalta Vladímir Propp (1992, p. 88), que "O exagero é cômico apenas quando desnuda um defeito"; no caso do romance, no entanto, essa noção se inverte, pois o que parece exagerado não é o objeto em si (a bunda), mas a "imaginação" do vendedor em relação ao que ele vê na "bunda" da moça:

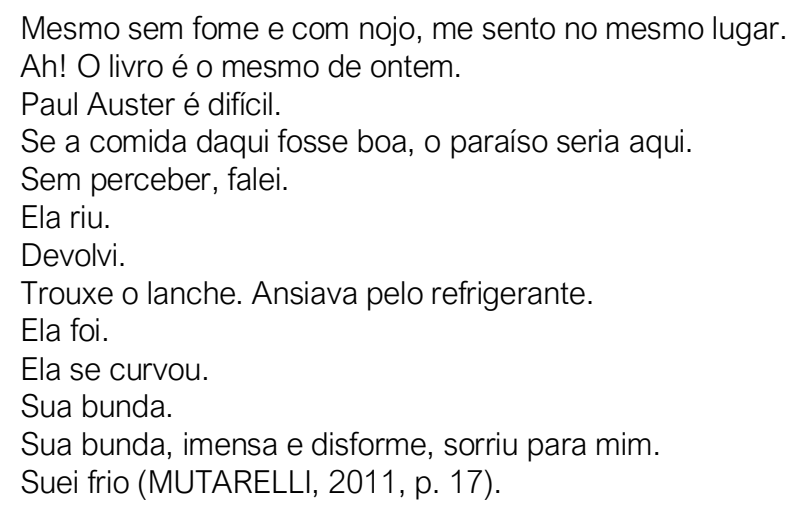

Percebemos pelo exemplo que o protagonista vai ao bar/lanchonete apenas para ver a moça que, na verdade, é apenas a "bunda": ele não gosta da comida e nem está com fome. De fato, até sente nojo do lugar. Apesar de o grotesco cômico geralmente destacar um defeito que existe, é exatamente desse "defeito" da "bunda" que o protagonista parece gostar. Por ser disforme, fora do padrão, a "bunda" o encanta, talvez, por ele mesmo apresentar um caráter disforme e gostar de coisas fora do convencional, pois assim é sua conduta durante toda a narrativa montada por Mutarelli. Propp, como vimos, explica que "O grotesco é cômico quando, como tudo o que é cômico, encobre o princípio espiritual e revela os defeitos" (1992, p. 92), levando-nos à constatação de que ele não vê a moça como um todo, como um "espírito", mas, sim, como um objeto: apenas a "bunda" e seus defeitos de formato - que o fascinam.

A deformidade, entretanto, parece projetar a visão distorcida do personagem principal, seu modo doente de ver o mundo e as pessoas. É assim que a visão exagerada entra na dimensão cômica. Ri-se de quem vê distorcidamente a bunda. Isso, porém, não anula um outro, senão primeiro, modo de perceber o exagero a desnudar um defeito: ao caricaturar a bunda da garçonete, seu "defeito" de mulher vulgar, sem instrução e leitora de revistas de astros de novela pode ser o alvo do protagonista, leitor de Paul Auster. Mutarelli, por conseguinte, se 


\section{$=$ TRAMA $=$}

valeria da ambivalência dos pontos de vista para realçar sua sátira, pelo viés do grotesco, tanto do vendedor quanto da balconista.

O grotesco também se revela em detalhes quando o protagonista afirma que "suou frio", pois os elementos que afetam o corpo grotesco são "o comer, o beber, as necessidades naturais (e outras excreções: transpiração, humor nasal, etc.)” (BAKHTIN, 1987, p. 277).

Notamos, assim, que o protagonista se interessa apenas pelo "baixo corporal" da moça, ou seja, sua "bunda", o que se conecta com a dimensão baixa de seus problemas que vêm, também, do baixo, do cheiro do ralo, que existe porque ele faz e revela por meio desses gases fétidos não apenas suas necessidades naturais, mas, também, sua interioridade, sua existência, se considerarmos que o ralo é uma forte metáfora da sua vida social e psíquica. Isto porque quanto mais o protagonista se isola, quanto mais destrata os outros, mais forte o cheiro vai ficando na loja que acumula velhos e, aparentemente, inúteis objetos.

O "baixo", teorizado por Bakhtin, revela, "No seu aspecto corporal, que não está nunca separado com rigor do seu aspecto cósmico, o alto é representado pelo rosto (a cabeça), e o baixo pelos órgãos genitais, o ventre e o traseiro" (1987, p. 19). Se tomarmos algumas convenções sociais como parte do "alto", o noivado, por exemplo, ele o rejeita, ao terminar repentinamente com a noiva que pensava amar (MUTARELLI, 2011, p. 13).

Aspecto igualmente marcante do grotesco é o fato de que o protagonista não consegue entender ou pronunciar o nome da moça e nem se lembrar de seu rosto, transformando-a em um ser-"bunda". Essa transformação rebaixadora efetiva o teor grotesco "[...] que visa apagar as fronteiras entre o corpo e o objeto, o corpo e o mundo e a acentuar essa ou aquela parte grotesca do corpo (ventre, traseiro, boca)" (BAKHTIN, 1987, p. 310, grifo do autor). Uma explicação para o fato de alguém, como o protagonista de Mutarelli, só conseguir enxergar no outro o traseiro e não seu rosto é considerada por Bakhtin. Ele explica que no estilo grotesco "O traseiro é o 'inverso do rosto', o 'rosto às avessas'" (BAKHTIN, 1987, p. 327).

Tal percepção nos conduz à ideia de paródia de um dos temas mais cristalizados na literatura amorosa ocidental: a obsessão causada pela visão de um rosto arianamente belíssimo, desde os líricos greco-latinos, passando pelos trovadores, até, pelo menos, os neoparnasianos, que preencheram seus poemas com descrições idealizadoras do rosto da mulher amada. Mutarelli inverte esse tópico e cria um personagem que se perde de desejo pelo traseiro da garçonete.

Na narrativa, essa percepção do avesso do rosto sugere o adoecimento afetivo e, por conseguinte, a visão misógina do protagonista, na medida em que ele apaga a identidade da mulher(seu rosto, seu nome e sua história) em prol de seu inverso: a bunda, elemento que dispensaria o protagonista de envolver-se afetivamente com "alguém", preferindo ele voltar-se apenas para "algo". Por esse ângulo, olhar "neutralmente" a bunda requereria dele somente uma visão destituída de humanidade, um olhar de vidro.

Isso nos leva a compreender um dos momentos fortes de $\mathrm{O}$ cheiro do ralo, quando o narrador-personagem depara um inesperado olho de vidro, objeto que o fascina e que ele compra sem hesitação (MUTARELLI, 2011, p. 36-37). Tal artefato se torna uma das metáforas fundamentais do romance, pois ele passa a interagir como se o objeto tivesse vida e, em seguida, o olho vira parte da construção de seu pai, um "boneco" que o protagonista cria juntando partes de objetos que compra e que representam a figura paterna que ele nunca conheceu. Além do olho, ele compra, mais tarde, uma perna mecânica e uma luva para montar seu "pai Frankenstein". A esse propósito, Kayser explica que "O elemento mecânico se faz estranho ao ganhar vida; o elemento humano, ao perder a vida. São motivos duradouros os corpos enrijecidos em bonecas, autômatos, marionetes, e os rostos coagulados em larvas e máscaras" (KAYSER, 2009, p. 158). 


\section{$=$ TRAMA $=$}

Em O cheiro do ralo, essa deformação ganha sentidos importantes na construção caracterológica do protagonista sem nome, mas que não levaremos em conta neste trabalho para nos restringirmos ao tema da configuração grotesca de personagens femininas.

Em uma outra passagem, o protagonista se encontra dizendo "Se essa bunda, se essa bunda fosse minha" (MUTARELLI, 2011, p. 21), usando como recurso humorístico a paródia de uma cantiga de roda popular: "Se essa rua, se essa rua fosse minha". Sobre esse tipo de paródia, Lima explica o que são os ditos populares alterados: "Comédia derivada de textos preexistentes que simplesmente são remodelados para produzir efeito cômico, alterando sons e significantes para que, igualmente, se alterem mundos visados, em verdadeiras antífrases, sem que, para isso, o eu lírico seja, ou saia desse jogo, afetado, modificado" (LIMA, 2011, p. 98).

Ditos populares, principalmente quando modificados e transformados em paródias, são fonte de humor e, segundo Propp, "A paródia é um dos instrumentos mais poderosos de sátira" (1992, p. 87). No caso da narrativa mutarelliana, a cantiga de roda, que remete ao mundo musical infantil, se ajusta perfeitamente ao motivo da paródia, uma vez que a bunda pertence a uma mulher que, embora seja adulta, se comporta paradoxalmente como criança (ao ler "tolices" em revistas comerciais, segundo o protagonista, mexendo com a boca), conduzindo seu "enamorado" à lembrança de textos voltados para a infância.

Mais adiante, já em casa, o protagonista é exposto pelo autor em um monólogo interior:

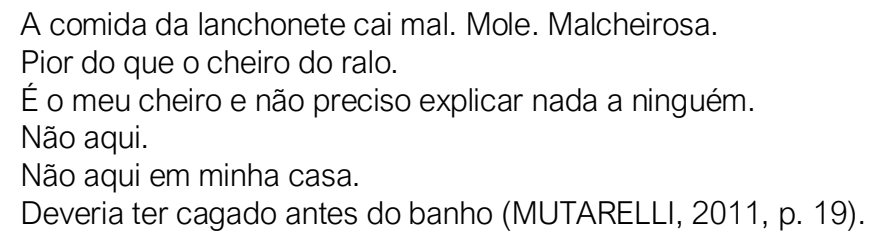

A cena narrada é propriamente grotesca. Como vimos nas explicações de Bakhtin, são figuras grotescas os "corpos que copulam, fazem as necessidades, devoram; os seus ditos giram em torno dos órgãos genitais, o ventre, a matéria fecal e a urina, as doenças, o nariz e a boca, o corpo despedaçado" (1987, p. 279). Além de o protagonista falar de suas necessidades e de sua matéria fecal no monólogo, ele retrata a comida da lanchonete de forma grotesca: "mole" e "malcheirosa". Podemos perceber que, pela primeira vez, ele assume que o cheiro é dele ("É o meu cheiro").

Paralelamente à imagem preponderante do ralo e da bunda, Mutarelli explora, ainda, como já antecipamos, um outro objeto de muita importância para a construção do estilo grotesco no romance: o olho de vidro. Eis o episódio que o introduz: um homem entra na loja do protagonista e tenta lhe vender um olho de vidro, alegando que o mesmo, além de ter muita história, também já viu de tudo, ao passo que o comerciante replica em pensamento: "De tudo, ele não viu. Penso eu. Não viu a bunda, isso ele não viu" (MUTARELLI, 2011, p. 36). Impressionado com o objeto, o protagonista paga um valor alto de dinheiro ao vendedor do olho, porque deseja transformá-lo em seu amuleto, além de querer levá-lo para ver a "bunda" (MUTARELLI, 2011, p. 36-37). Ou seja, ele compra o olho apenas para que o objeto tenha visto de tudo - e o que falta para ele ver é a "bunda". Ele adquire o olho, primeiramente, por causa da "bunda".

Sobre o efeito do olho no mundo grotesco, Kayser explica que "o próprio isolamento dos olhos atua de modo sinistro e estranhador. Obriga-nos, com isso, a reconhecer todo o conteúdo significativo que os olhos aqui recebem: os olhos como expressão da alma, os olhos 


\section{$=$ TRAMA $=$}

como vinculação com o mundo, os olhos como "força vital propriamente dita" (KAYSER, 2009, p. 71).

O comentário de Kayser nos permite analisar o objeto adquirido pelo protagonista. Ele acolhe "o olho" como uma quase entidade, a qual atribui poderes e, estranha e simbolicamente, certa "força vital". Embora a explicação do teórico se refira ao olho humano, o olho de vidro na narrativa mutarelliana mantém essa "humanidade" de modo insólito, já que o objeto parece projetar o olhar do protagonista, sua própria alma, uma vez que o mesmo inventa que o olho de vidro era de seu pai que morreu na guerra, cobrindo assim aparentemente uma lacuna em sua história - a de que nunca conheceu o pai (MUTARELLI, 2011, p. 37). Dessa forma, ele passa a mostrar o olho para todos os seus clientes e até mesmo para pessoas fora de seu trabalho como se fosse do falecido e desconhecido pai. Há apenas uma exceção: o entregador de pizzas que vai ao seu apartamento, para o qual ele inventa que o olho veio dentro de uma pizza (MUTARELLI, 2011, p. 39). Ademais de toda essa farsa, o protagonista acredita que, de alguma forma, o olho amplifica o seu poder, atribuindo-Ihe sorte e proteção (MUTARELLI, 2011, p. 3940), isto é, deixa-o com menos medo das coisas que lhe vêm acontecendo, como o medo da culpa.

Além da composição grotesca da personagem garçonete-"bunda", reforçada pelos elementos que observamos, Mutarelli reforça a caracterização estranha do protagonista por meio de outra personagem feminina igualmente negativa, a ex-noiva.

\section{“ESTIVE NO INFERNO E LEMBREI DE VOCÊ": a noiva}

Antes de se envolver com a garçonete, o protagonista desenvolvia uma relação perturbada com sua (ex) noiva, outra personagem feminina que revela desfechos grotescos. Depois do primeiro encontro com a "bunda", o protagonista está em casa com sua então noiva, onde eles têm uma discussão. Eles iriam se casar e os convites do casamento já estavam na gráfica. Embora ela imaginasse que seriam felizes, o protagonista não pensava da mesma forma, porque desacreditava em felicidade ("coisa de ingênuos", segundo ele), o que desestabiliza a noiva, levando-a ao choro. A discussão leva o narrador-personagem a the dizer que não quer se casar mais. A cara de desespero que ela expressa é descrita como "engraçada", revelando seu humor maldoso. Assim, o personagem principal desfaz o casamento, falando que nunca gostou dela e nem de ninguém, ao passo que a mulher continua a chorar "de uma forma engraçada", da qual ele ri, enquanto é chamado pela ex-noiva de louco (MUTARELLI, 2011, p. 12-13).

Esse riso maldoso define em muito o caráter e as ações do protagonista no romance. Mutarelli compõe esse personagem no estilo grotesco, de modo a sugerir um tipo comerciante culto (negocia quinquilharias de modo arbitrário) que, perdido em seu tédio, não vê o mundo senão pela ótica negativa, melancólica, desesperadamente "malcheirosa". Nessa composição caracterológica, Mutarelli explora o humor e o riso maldosos como traços relevantes do protagonista, de modo a refletir sobre os comportamentos urbanos brasileiros contemporâneos. A propósito, Propp detalha mais sua observação sobre esse tipo de riso:

Deste riso, em geral, riem as pessoas que não acreditam em nenhum impulso nobre, que vêem em todo lugar a falsidade e a hipocrisia, os misantropos que não compreendem como por trás das manifestações exteriores de boas ações haja realmente alguma louvável motivação. [...] Os homens generosos ou dotados de uma sensibilidade superior são para eles uns tolos ou uns idealistas sentimentais que só merecem escárnio. [...] Este riso não suscita simpatia (PROPP, 1992, p. 159). 


\section{$=$ TRAMA $=$}

Reforça essa noção o episódio da visita da ex-noiva do protagonista ao seu local de trabalho com uma faca na mão, jurando matá-lo. Ele pede que ela se acalme. Eles se abraçam e ela começa a dizer que o quer de volta, mesmo que exista outra "vadia", que o aceita de qualquer maneira e começa a seduzir o personagem principal. O protagonista, então, força a própria cara na bunda dela, como se quisesse entrar. Depois, "Ela levanta a saia e puxa de lado a calcinha. Afasta os lábios e mostra a grutinha. É isso que você quer? É para isso que você dá valor? Meu pau até dói de tão duro" (MUTARELLI, 2011, p. 22), e a ex-noiva começa a chorar ao mesmo tempo que o convida "a entrar", enquanto ele esfrega a cara na "grutinha" dela, melando-se e, antes que pudesse fazer algo mais, ele goza:

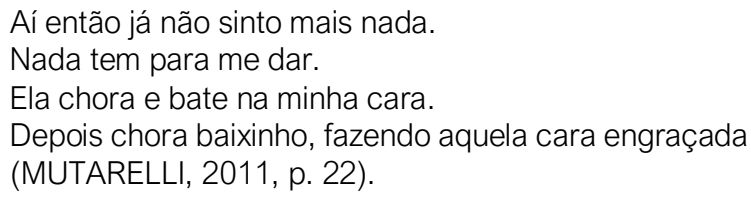

Além de esse episódio demonstrar, mais uma vez, a superioridade do protagonista em relação aos outros ("Nada tem para me dar") e sua falta de empatia com a ex-noiva, que chora "fazendo aquela cara engraçada", ele reforça a ideia de grotesco, à medida que, na cena erótica, o comerciante menciona a vagina da ex-parceira como uma "grutinha" - nome não oficial dos órgãos genitais - e expõe a imagem do corpo que excreta ("a vagina melada") e copula. Confirma essa inferência a ponderação de Bakhtin:

[...] além disso, as imagens grotescas do corpo predominam na linguagem nãooficial dos povos, sobretudo quando as imagens corporais se ligam às injúrias e ao riso; de maneira geral, a temática das injúrias e do riso é quase exclusivamente grotesca e corporal; o corpo que figura em todas as expressões da linguagem não-oficial e familiar é o corpo fecundante-fecundado, parindo-parido, devoradordevorado, bebendo, excretando, doente, moribundo; existe em todas as línguas um número astronômico de expressões consagradas a certas partes do corpo: órgãos genitais, traseiro, ventre, boca e nariz, enquanto aquelas em que figuram as outras partes: braços, pernas, rosto, olhos, etc., são extremamente raras (BAKTHIN, 1987, p. 278-279).

Sobre essas outras partes que cita Bakhtin (1987), entre as quais figura o "alto corporal" (o rosto e os olhos), percebemos que o protagonista nunca faz menção a elas - exceto quando se interessa pelo "olho de vidro", avesso paródico dos olhos -, preocupando-se obstinadamente com o baixo corporal.

A ex-noiva, assim como a garçonete e o protagonista, não possui um nome, não apresenta um rosto. Sobretudo, elas são o "traseiro" e a "vagina", que é o que importa e o que ele quer possuir. Portanto, como protagonista, o homem grotesco ignora a superfície "alta" do corpo e "[...] ocupa-se apenas das saídas, excrescências, rebentos e orifícios, isto é, unicamente daquilo que faz atravessar os limites do corpo e introduz ao fundo desse corpo" (BAKHTIN, 1987, p. 277).

Já em casa, o protagonista, assistindo à TV, começa a sentir medo por conta de um vulto que acha que viu:

Percebo uma coisa estranha.

Um vulto, ou algo assim.

Pela visão periférica, desloca-se.

Me viro rapidamente. Pensei ser alguém atrás de mim.

Nada. 


\section{$=$ TRAMA $=$}

Algo da natureza dos vultos. Uma sombra. Uma ilusão. O passado (MUTARELLI, 2011, p. 23-24).

Em seguida, o pai de sua ex-noiva o avisa ameaçadoramente por telefone que ela tinha feito uma lavagem estomacal, pois tomara duas caixas de Lorax, tentando se matar. O protagonista imagina "baldes, repletos de merda e amarelos Lorax" (MUTARELLI, 2011, p. 24), e, não se importando, continua a ver TV.

O grotesco se realiza na referência amedrontadora do vulto, pois "O grotesco é 'sobrenatural' e 'absurdo', isto é, nele se aniquilam as ordenações que regem o nosso universo" (KAYSER, 2009, p. 30). Ou seja, tudo que sai da "normalidade" da vida, pode ser considerado próprio do universo grotesco. Assim, o suicídio malogrado e a lavagem estomacal com baldes de merda e Lorax amarelo resultam não propriamente em drama no romance, mas em um melodrama banal que se mescla, por isso, ao cômico. Kayser (2009, p. 57) relaciona o trágico e o ridículo, pois considera que "o grotesco abre agora um caos espantoso que é, ao mesmo tempo, ridículo. Uma nova palavra coloca-se bem perto do grotesco: tragicomédia”. Tragédia misturada com comédia: a cena grotesca faz com que riamos, mesmo sendo um riso cruel, pois o grotesco, segundo Kayser (2009, p. 14), ficou se "arrastando" pelos livros de Estética como uma "subclasse do cômico, ou mais precisamente, do cru, baixo, burlesco, ou então, do cômico do mau gosto".

Ainda tratando da composição do estilo grotesco com relação à personagem ex-noiva em $\mathrm{O}$ cheiro do ralo, outro exemplo muito significativo é o envio de um sapo, provavelmente por ela (não se confirma, no entanto, se foi mesmo ela, mas o protagonista acredita que isso seja "coisa da ex" [MUTARELLI, 2011, p. 85]), com a boca costurada, dentro de uma caixa para o ex-noivo:

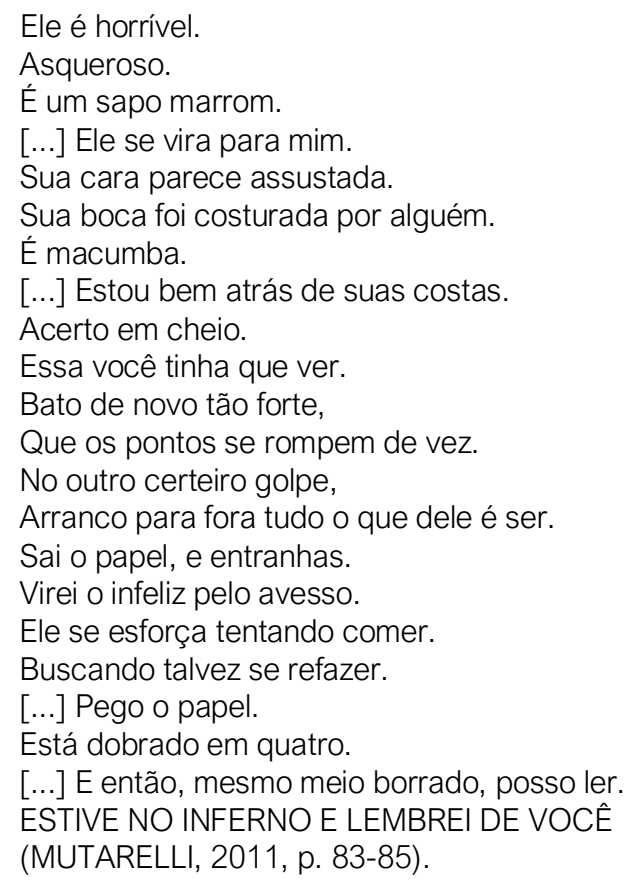

Esse trecho carrega vários exemplos de grotesco, agora no plano do horrível relacionado ao mundo animal. Existem bichos que são "[...] preferidos pelo grotesco, como serpentes, corujas, sapos, aranhas - animais noturnos e os rastejantes, que vivem em ordens diferentes, inacessíveis ao homem" (KAYSER, 2009, p. 157). Por esse ângulo, a presença do sapo exacerba a imagem grotesca e consolida, no romance, o sinistro. $O$ fato de o sapo estar 


\section{$=$ TRAMA $=$}

com a boca costurada implica uma dimensão religiosa negativa para o protagonista, porque relacionada com "macumba", cujo objetivo é prejudicar alguém com feitiços e magias. Nesse episódio, percebe-se a vulnerabilidade psíquica do protagonista no momento em que ele se preocupa com o que o sapo poderia ter em seu interior. Ele o esmaga com uma vassoura, fazendo-o "cuspir" suas entranhas, consoante "[...] a imagem grotesca [que] mostra a fisionomia não apenas externa, mas ainda interna do corpo: sangue, entranhas, coração e outros órgãos" (BAKHTIN, 1987, p. 278), neste caso, de um animal asqueroso, o que duplica a monstruosidade.

Percebemos o medo do protagonista diante da "macumba" feita no sapo. No bilhete inserido na boca do animal, o protagonista lê a frase "Estive no inferno e lembrei de você". Emblemática, a frase comove o protagonista, levando-o a acreditar que o ralo é o portal do inferno, inferno esse que representa sua própria vida indo de mal a pior.

No imaginário grotesco, o inferno tem papel de importância, assim como a paranoia do protagonista, atualização da loucura, própria desse estilo: "O grotesco romântico conduziu o cômico para o fantástico, o horrível e a loucura" (MINOIS, 2003, p. 535). Esta é considerada, aliás, como "uma das percepções primigênias do grotesco que a vida nos impinge. [...] o mundo grotesco causava a impressão de ser a imagem do mundo vista pela loucura" (KAYSER, 2009, p. 159), de que o romance de Mutarelli nos dá diversos exemplos.

\section{CONCLUSÃO}

Ao final do romance, quando o personagem principal finalmente se encontra com a "bunda", apesar de ter ficado emocionado e se sentido realizado, logo após o ato - ele paga a moça para mostrar a "bunda" enquanto se masturba olhando-a. Em seguida (sem chegar ao gozo), vai até a mesma e a abraça com força, com medo de ser puxado pelo ralo e, então, desata a chorar "feito um bebê". Ele se sente vazio, porque o que buscava não era a "bunda", mas, sim, a busca em si (MUTARELLI, 2011, p. 170-171). A moça, que não sabe o que fazer ao vê-lo chorar, passa a fazer sexo com ele e, quando terminam ele narra:

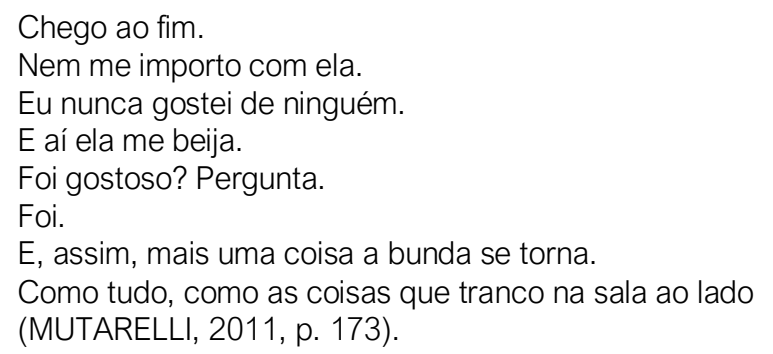

Assim, a "bunda", que passa a ser mais uma coisa adquirida por ele, se torna nada.

Neste artigo procuramos expor uma análise da realização do humor grotesco na configuração de duas personagens femininas que Lourenço Mutarelli desenvolve em seu romance/livro/obra O cheiro do ralo. A sátira, a paródia e o grotesco são, como vimos, alguns dos aspectos em que seu texto humorístico se desdobra, provocando o riso e desencadeando a reflexão sobre os comportamentos dos homens e mulheres urbanos enclausurados em sua individualidade desestabilizada.

Nessa lógica de observação crítica da atualidade, o grotesco e o humorístico na obra são justapostos, de maneira a sugerir as relações infernais e paranoicas do protagonista com a garçonete e a ex-noiva, personagens que atuam como metáforas da psique do protagonista e revelam o grau de crise existencial de um comerciante de quinquilharias. 


\section{$=\mathrm{T} R A M A=$}

\section{REFERENNCIAS}

BAKHTIN, Mikhail. A cultura popular na Idade Média e no Renascimento: o contexto de François Rabelais. Tradução de Yara Frateschi Vieira. São Paulo: Hucitec, 1987. 419 p.

BREMMER, Jan; ROODENBURG, Herman. Introdução. In: . Uma história cultural do humor. Tradução de Cynthia Azevedo e Paulo Soares. Rio de Janeiro: Record, 2000. p. 13-25. HOUAISS, Antônio; VILLAR, Mauro de Salles. Dicionário Houaiss da Língua Portuguesa. Rio de Janeiro: Objetiva, 2009. 1.986 p.

HUGO, Victor. Cromwell. Bruxelles: Meline, 1843. 615 p.

HUGO, Victor. Do grotesco e do sublime. São Paulo: Editora perspectiva, 2010. 104 p. KAYSER, Wolfgang. O grotesco. Tradução J. Guinsburg. São Paulo: Perspectiva, 2009. 164 p.

LIMA, Roberto Sarmento. Duas notas sobre o humor na literatura. In: SANTOS, Herbert Nunes de Almeida; SILVA, Susana Souto (Org.). Trilhas do humor na literatura brasileira. Maceió: Edufal, 2011. p. 85- 99. MINOIS, Georges. História do riso e do escárnio. Tradução de Maria Elena O. Ortiz Assumpção. São Paulo: Unesp, 2003. 654 p.

MOISÉS, Massaud. Dicionário de termos literários. São Paulo: Cultrix, 2013. 535 p.

MUTARELLI, Lourenço. O cheiro do ralo. São Paulo: Companhia das Letras, 2011. 184 p.

PROPP, Vladímir. Comicidade e riso. Tradução de Aurora Fornoni Bernardini e Homero Freitas de Andrade. São Paulo: Ática, 1992. 216 p.

ROBLE, Odilon José; ARAÚJO, Raíssa Guimarães de Souza. Introdução ao Grotesco nas Artes da Cena.

Revista Pós. Programa de Pós-graduação em Artes da EBA/UFMG. Belo Horizonte, v. 6, n. 11, p. 148-159, 2016. Disponível em: <https://www.eba.ufmg.br/revistapos/index.php/pos/article/view/325/pdf>. Acesso em: 17 abr. 2019.

SODRÉ, Muniz; PAIVA, Raquel. O império do grotesco. Rio de Janeiro: MAUAD, 2002. 156 p.

TRAVAGLIA, Luiz Carlos. Texto humorístico: o tipo e seus gêneros. In: CARMELINO, Ana Cristina (Org.).

Humor: eis a questão. São Paulo: Cortez, 2015. p. 49-90. 